各部の保溫は厚さを倍化するとともに，マンホール カバーその他露出部は一切塗りつぶした。

（へ）原料タール

安水は冷却器前後を混合し, 遂次更新するとともに 極力静置による脫水につとめ，原料タール水分を2〜 $2.5 \%$ 程度に低下せしめ, カスケード式脫水設㣁によ るガス加熱を不必要とした。

\section{(VI) 結言}

1）各設備別に材質腐蝕の状況学詳述し，油 が溫度差により㠜縮い蒸発の状態におかれる相に おいてもつともはげしいことを明らかにした。

2）材質腐蝕の原因は，效タールの Erosion, 油氛の

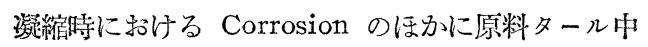

の腐蝕成分に基づくものと考元られる点について述 べた。

3）腐蝕に対する材質的検討, 並びに原料タールの品 質改善について種々考究し，材質は踳鉄と 18-8鍓 に变換するとともに，安水中の無穖壏類がタール中 に沈積するのを極力さけるようにした。

4）保溫完完全にして部分的未保溫個所に上る油気の 凝縮時腐玲作用を防止した。

5）現在安定した満足な操鄴きつづけている。 追記 本設備の改善策に関して終始熱心なる御指導 そ助言を賜つた長崎化工部長に梁甚なる感謝の意を表 します。

\title{
Corrosion of Pipe Still for Distillation of Tar
}

\author{
By Yujiro Yamamoto and Terumichi Takahashi
}

(Kamaishi Works of Fuji Iron \& Steel Co.)

\begin{abstract}
SYNOPSIS:-The severe corrosion of pipe still for tar distillation at Kamaishi Iron Works is reported. The authors describe the outline of the installation and the conditions of corrosion for each part of the installation. The most severe corrosion was seen at the heating pipes and the oil condensing part of fractionating column. The corrosion appeared to be due to the presence of anions in ammonia liquor and tar. As the anticorrosive treatments, $18-8 \mathrm{Ni}-\mathrm{Cr}$ steel was used for heating pipes and packings in fractionating columns, and the shell of fractionating column was changed to cast iron made.
\end{abstract}

U. D. C. $621.45+662.75$

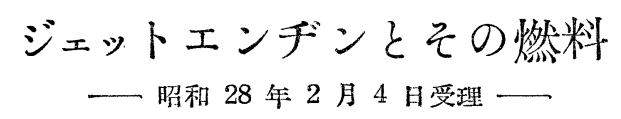

三菱石酒株式会社研究部 小 幡 武 三

要旨 筆者は,まずジェット・エンヂンの利点, 往復ェンヂンとの相違, 性能, 種類などについて說 明せる後，その燃料について，欧米の実用機使用燃料の規格，燃燒特性，高度にょる揮発性の差異， 流動性と濾過性，始動性とカーボン附着性などについて述べわが国に扎いてその規格範囲を決定す る場合, 多くの基本的, 実用的研究が必要であるととを指摘した。

\section{(I) 緒 言}

第二次大戦中に現われたジェット・エンヂン航空穖

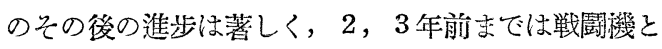
しての優秀性は認められたが，商澲機としての実用化 にはな相当の時日を琶するだろらとの想が外国の 工業評論家の間で行われていた。また現在において
も，米国のある一部の人々によつてジェット・ェンヂ ンと往復ェンヂンの航空ェンヂンとしての地位の変化 は1950年代の終りごろだろうとの観測が行われてい。 るが，事奏の上で既に英匤ではコメットその他の商業 穖が㓞用化されて，わが国にも試験的に飛来して来た 等のことから，わが国の各方面にジェット・ェンヂン 
への関心を强むるに至り，既に国內各種の文献にこの 種の調查研究が発表されている。このような関係か ら，重ねてここに頭書のような調查紹介を行らことは 衆知のことと重複する点の多くあることを案ずるもの であるが，あ兄て以下簡単にェンヂンの概略とその燃 料の性状とェンデンの性能の関係について記述するこ ととする。

\section{（II） ジェット・エンヂンの特徴}

筆者の專門外の事項であるから基本的理論の項に関 しては避けて，一般概略についての紹介にとどむるこ ととする。 。

$$
\begin{aligned}
& \text { 1. ジェット・エンデンと往復エンヂンの比較 } \\
& \text { ジェット・エンヂンの利点は次のとおりと言われて }
\end{aligned}
$$
いる。

(1) 振動がないから据附設備が簡単で軽くて良い。

(2) 調整簡単で速度の調整は一本の挺子で可能であ る。

（3）加熱または冷却設備が不要である。

（4）冷却空気が不要である。

（5）一度始動すればその後は点火栓の使用が不要で ある。

（6）キャブレッターが不要である。

（7） 圧縮空気を使用するため，室內に過給穖使用の 場合のよらにガンリンなどの油蒸気の大る盧れがな い。したがつて火災の盧れが少ない。

(8) 渾転が静かである。

（9）エンデンの重量が比較的軽い。

基本的な往復エンヂンとの差違は下記のと拈りと報 じられている。

（1）高速飛行の場合に効率は良い漓陸低速の場合 は惡い。

（2）エンデン重量は往復エンヂンの $1.71 \mathrm{~b} / \mathrm{P}$ に対 して 0.4〜0.851b/: $\mathrm{P}$ スストのよ弓に俥い。

（3）燃料消費率は，往復エンデンでは最高出力の中 間程度の場合最少であるのに対して, 最高出力近く で最少であるが実際燃料消費量は大である。

（4）往復エンデンは高度によつて速度が変るが，ジ エット土ンヂンは高度に対して速度は一定である。 機関の性能については

(1) 往復エンヂンの最高速度 335 マイル/時 程度に 対して, 実用ジェット・ェンデンは最高速度 610 マ イル/時ぐらいまでは可能である。

（2）航空機の設計上往復エンヂンは飛行距離 9,500 マイル程度の場合に平均最高速度が得られるのに対 しジェット・ェンヂンでは 2,500 マイ以下である。
以上のよらな点からジェット・ェンヂンの研究がま 寸ま寸盛んとなつたものと思れれる。

2. ジェット・ェンヂンの種類

ジェット噴射によるェンヂンを分類して次ぎのと打 りとする。

(1) Gas Turbines (Turbo jets) 略号 J

(a) Centrifugal-flow

(b) Axial-flow

(c) Turbo-prop. (一般に Axial-flow 型にプロ ペラを附けたものである)

略号 $\mathrm{T}$

(2) Athodyds

(a) Pulse Jet

略号 PJ

(b) Ram Jet

(3) Rockets

(a) 固体燃料

(b) 液体燃料

その抢の扮のの構造，特徽は第1〜 7 図に示す略図 のとおりである。

ロケットおよび Athodydes は高速度を出し得る特 徽を有しているが，始動の困蜼，設計抢よび材料の困 䧼の他, 第 1 表のとおり燃料の消費量が大なるために, 実用ェンヂンは特殊のものを除きほとんどターボ・ジ エットに限られている。

米軍で探用されているェンヂン標示法は, 最初にェ ンヂン種類の略号を記し, 次ぎに数字でその型式を示 し，その次に製作会社名の頭文字を並べ，最後に改良 順位を示す。型式を示寸数字は, 米空軍は奇数をとり, 米海軍は偶数をとる。最後の数字の最大なものは最新 式のものを表わすものである。例によつて示すと次ぎ のと频りである。

$$
\begin{aligned}
& \mathrm{J} 33-\mathrm{A}-23 \text { 米空軍用33型アリソン製改良23型 } \\
& \text { ターボ・ジェット・エンデン }
\end{aligned}
$$

\section{第 1 表 航空エンヂン燃料消費量}

$\begin{array}{lcc}\text { 過給機附往復エンデン } & 0.55 & 1.0 \\ \text { ターボ・ジェット } & 1.70 & 0.7 \\ \text { Pulse Jets } & 4.00 & 0.5 \\ \text { Rum Jets } & 3.30 & 0.2 \\ \text { Rockets } & 15.0 & 0.15 \sim 0.30\end{array}$


第1図 Centrifugal Flow Turbo Jet
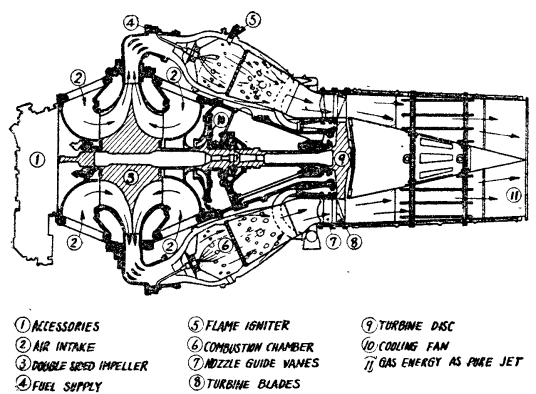

\section{第 2 図 Axial-Flow Gas Turbine}

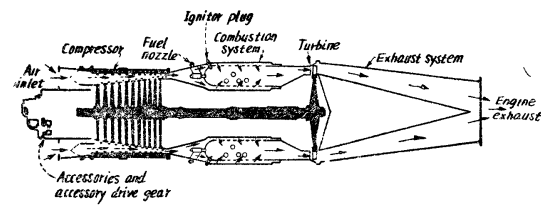

第3図 Gas Turbine Propeller Engine

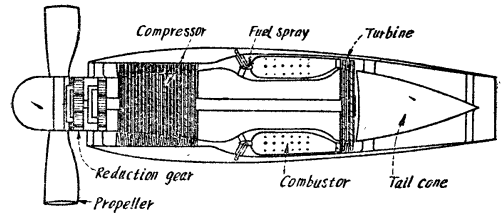

第4図 Pulse Jet (Athodyd)

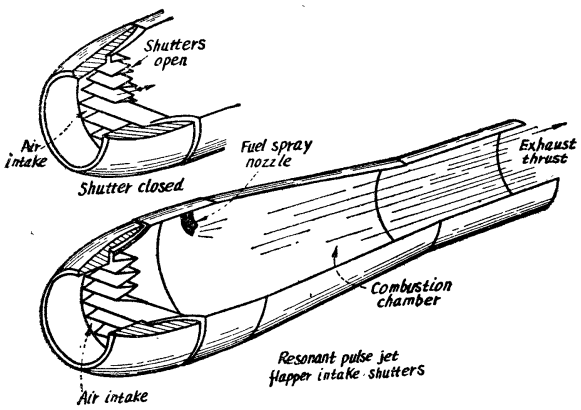

第5図 Ram Jet (Athodyd)

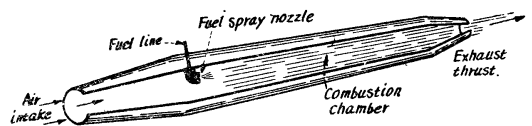

第6図 Rocket, Solid Fuel

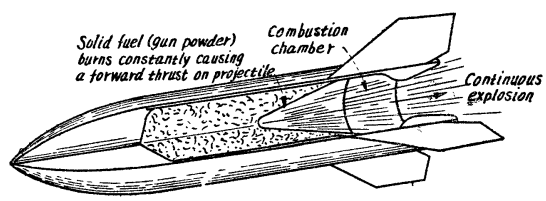

第 7 図 Rocket Liquid Fuel

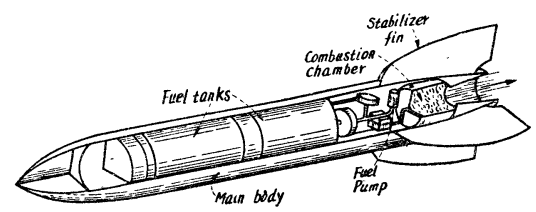

第 8 図 Fuel System with Dual-purpose Booster Pump for Emergency Duty

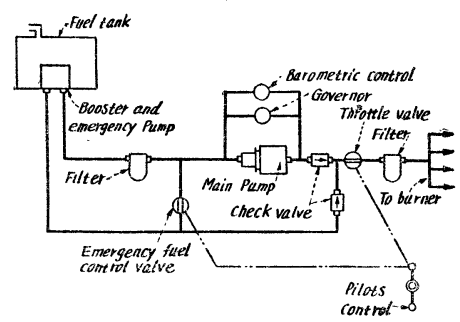

3. ターボ・ジェット・ェンヂンの然料系統その他 実際的には調節, 非常用自動切換など種々複雜な権 造を有しているもののようで，またその型式も種々異 るものが多いようであるが，ある種のものの概念的系 統略図は第8困のと特りである。

エンデンの地上始動に当つては, 始動調整裝置を使 用して比較的濃厚混合気として点火栓を用い一部がバ ーナに点火しタービンの回転が規定速度となつた時 に燃料濃度を下げて全部に点火する。離陸または急上

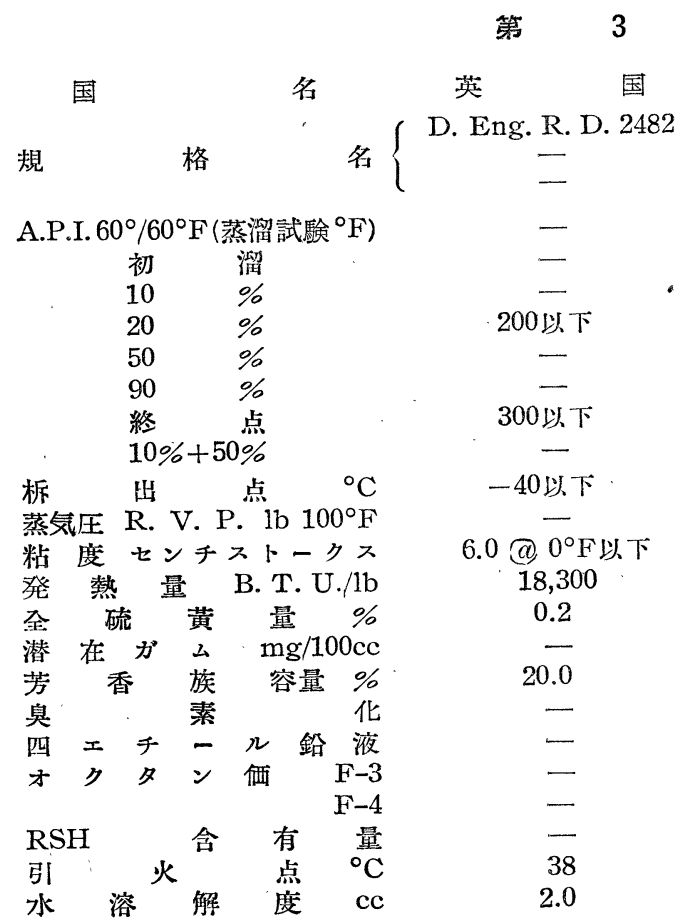


后などの急激にスラストを潧大する要のある時は，燃 燒公への水噴射むたはティル・パイプ (排気管)のア フター・バーナで然燒を行らなどのことが行われる。

\section{（III） 航空用ジェッ卜燃料}

1. 実用穖の使用燃料とその規格

現在欧米に怙ける実用穖の使用燃料は第 2 表の々お りと報じられている。もちろん最薪の軍用穖について はらかがい知ることはできないが，これによつてその 大略は知り得ることと思う。

\section{第 2 表 航空機種別ジェット燃料 \\ 機種名 \\ 英

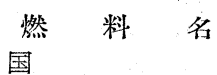

Armstorong Siddeley Python 142

Armstorong Siddeley Mamba ASM3

Armstorong Siddeley

Double Mamba

Bristol Theseus 502

Bristol Proteus

Bristol Coupted Proteus

De-Havilland Goblin 35

Napier Naiad

Rolls-Royce Derwent 5

Rolls-Royce Nene
灯油 D. Eng. R. D. 2482

灯油 D. Eng. R. D. 2482

灯油 D. Eng. R. D. 2482

灯油 D. Eng. R. D. 2482 灯

灯油 (比重 0.81)

灯油 D. Eng. R. D. 2482

灯油 D. Eng. R. D. 2482

灯油 D. Eng. R. D. 2482

灯油 D. Eng. R. D. 2482
The Rateau SRA-101 ガッリン, 灯油
Snecma ATAR 101C Norme Air 3405

Turbomeca Pimene 灯沘 スェーデン

Svenska ?

Allison J-33 米

Allison J-35-A-21

Boeing Model 500

General Electric J-47GE-23

The pratt \& Whittney J-34 Turbo-Wasp

Pratt \& Whittney J-42

Turbo-Wasp

Westinghouse J-34

$$
\begin{aligned}
& \text { 国 } \\
& \text { ガッリン, 灯油 } \\
& \text { 灯油, J. P-1 } \\
& \text { ガッリン, 灯油, 軽油 } \\
& \text { J. P-1, ガソ リン } \\
& \text { ガソリン, 特殊燃料 } \\
& \text { ガソリン (100/130) } \\
& \text { ガッリン (AN-F-48) }
\end{aligned}
$$

表で見ると怙り，欧洲では主として灯油系統の燃 料を使用し，米国では灯油並びにガッリン系両種類の わのを使用している。米国内でこの傾向をエンデシ製 作会施別に見ると，アッッン，ボーイング両者は灯油 系, G-E，プラット・アンド・ホイットニーおよびウ エスティング・ハウスなどはガンリン系のものを使用

しているように考觉られる。

いずれにしても，その使用燃料の種類は在来の往復 動航空ェンヂンに比して，その範团が広いことがわか る。

次ぎにその規格を第 3 表に示す事とする。

表

$$
\text { ジエット燃料規格表 }
$$

米

（概 略）

国

Grade J. P-1 Grade J. P-2 Grade J. P-3

AN-F-32a

Mil-F-5616 AN-F-34

AN-F-58

- Mil-F-5624

35以上

210以下

65 以上

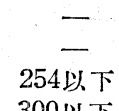

300以下

-

45-63

-60 以下

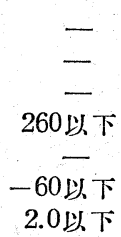

$10.0 @ 40^{\circ} \mathrm{F}$ 以

2.0 以下
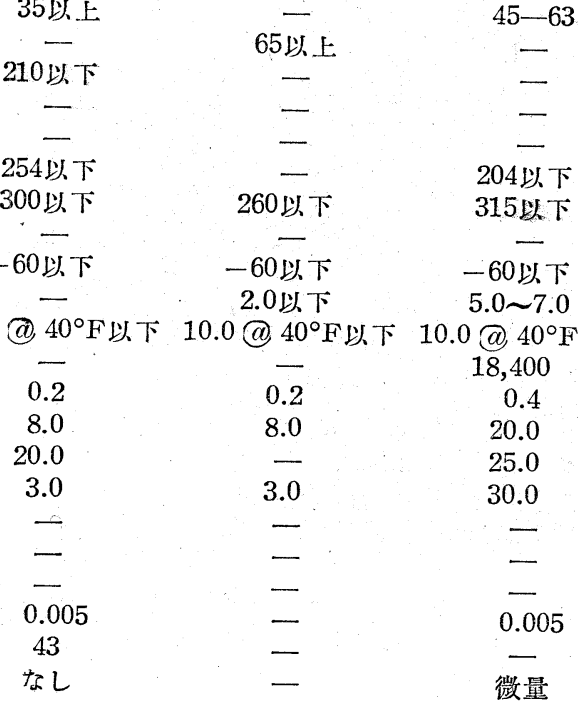

0.2
8.0
-
3.0
$=$
$=$
$=$
-

$5.0 \sim 7.0$

$10.0 @ 40^{\circ} \mathrm{F}$ 以下

8.0

3.0

$-$

43

(2) 40
18,400

0.4

20.0

25.0

30.0

-

0.005

微量

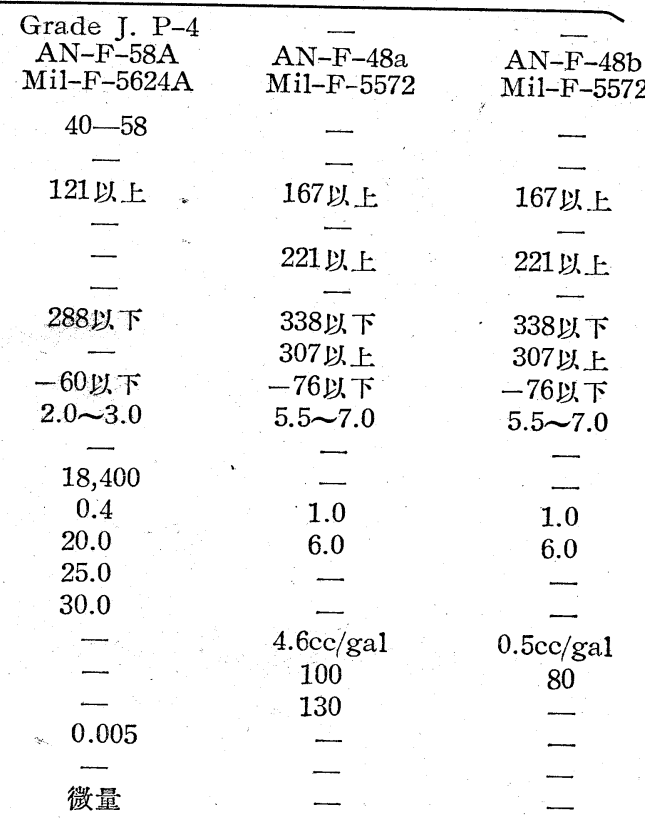


第 3 表に示したいずれの梘格においても, その㠜固 点は寸こぶる低くとつていることがこの然料の特徽で あるが，その他の項目については各種類によつてその 限度に相当の巾があつて概念的にその特質を知ること は困難であるが，ジェット燃料としての必要條件並で にその性状の実用上に及ぼす影響について次ぎに記述 することとする。

2. ジェット・エンヂンにおける然燒特性

ジェット・ンヂンのタービンの犲根はほぼ $820^{\circ} \mathrm{C}$ 以上には耐え得ない。このため燃堯溫度を低下さし て, タービン・ガイド・ベイン大口でその溫度を $890^{\circ} \mathrm{C}$ 以下とすることが必要であるといわれている。 以上の理由から空気燃料比は $55: 1 \sim 120: 1$, 場合に よれば $600: 1$ のように非常に然料濃度を低くしてい る。またその燒燒速度について考方立場合には燃燒室 の長さ $2 \mathrm{ft}$ 程度を普通とし, 全速の場合秒速 $100 \mathrm{ft}$ 程 度とするから，ほぼ0.02秒で全然堯が完了しなければ ならないこととなる。ガスタービンの出力は空気燃料 比を調節して加減を行らことが多いから，飛行中その 比を変更する場合子多い。このような関係で燃燒窒內 の溫度が過度に低下して消火しないために, 燃譊室內 で 20,000,000B.T.U/ft ${ }^{2} / \mathrm{hr}$ 程度の然燒を行弓のか潽 通で，一般工業用炬の場合の10〜20倍の燃料を燃燒せ しめているようなことが特に他の燃燒法と異る点であ る。

これらの点から然桎特性の優秀性といらことが一つ の問題となる。蒸発性および炭化水素の組成によるそ の善異の比較は, 第9困およで第10図のとおりである。

\section{第 9 図 パラフィン系燃料の蒸発性と燃燒効率}

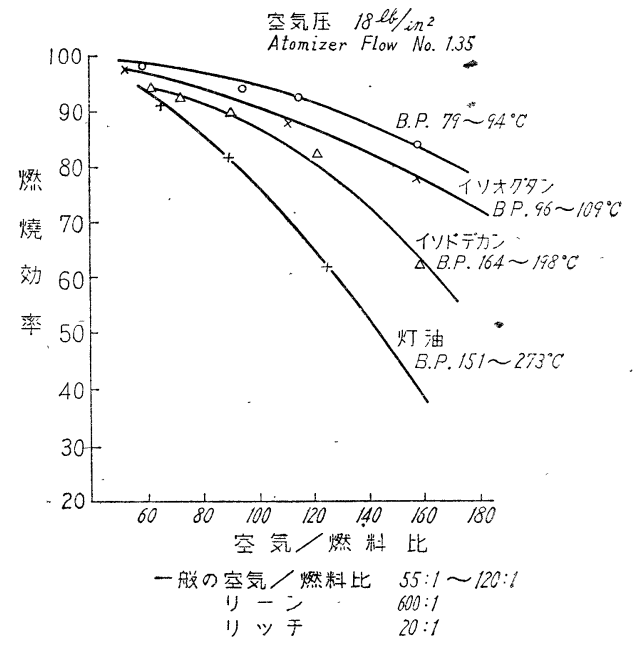

\section{第10図 炭化水素組成による燃燒効率}

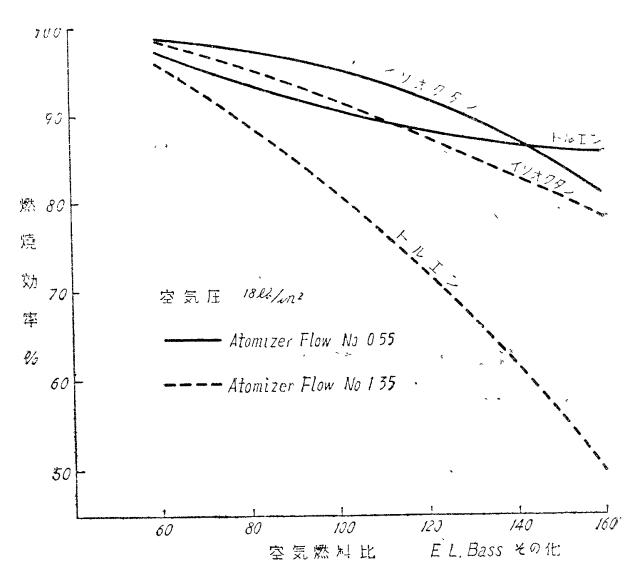

3. 高度による揮発性の差暴

ジェット蟣は, 衆知のと抢り航行高度が非常に高く， しかも上昇速度が大であるから, 気圧の羑異による影 響から種々な問題が生ずる。その関係は第11四怙よび 第12図むるいは第13図のとおりである。

第 11 図

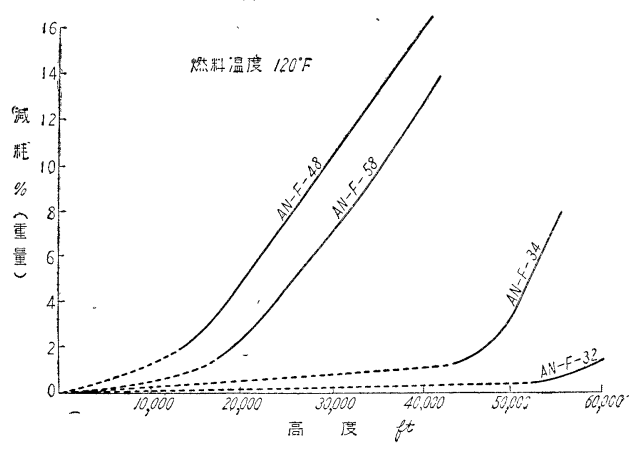

第 12 図

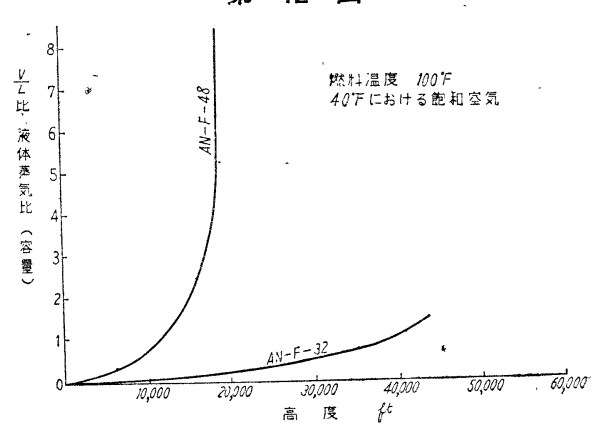


第 13 図

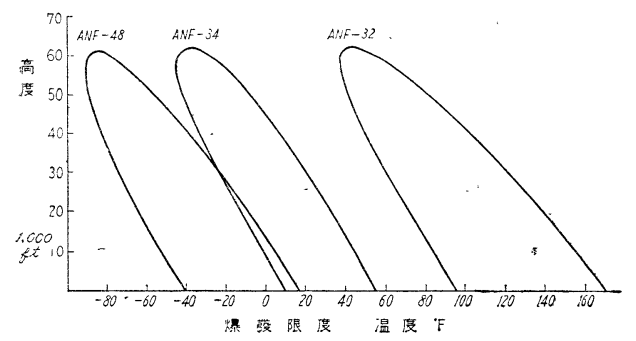

これらの表で見ると扮り，軽質のものは著しくガス 化することが多いために，ベイパー・ロックを避ける 饫の特別のポンプその他の考慮を必要とする欠点を 有するも，爆発限度は狹い利点がある。

4. ジェット燃料の流動性並びに濾過性

前述したとおりに，単位容積当り燃燒燃料が非常に 多いことと燃料濃度が薄いために，均一の燃燒を行う なめには精密な調整設備と濾滑穖によつて常に流量を 調整し得ることを必要とし，從つて適当な流動性と濾 渦性を必要とする。これらの係数となり得るものは粘 度, 析出点, 水の溶解度である。これらの関係は, 第 4 表，第14図抢よで第15図のと抬りである。

\section{第 4 表 ジェット燃料の粘度}

(単位 センチストークス)

\begin{tabular}{|c|c|c|c|c|c|c|}
\hline \multirow{2}{*}{ 燃料名 } & \multicolumn{3}{|c|}{$100^{\circ} \mathrm{F}$} & \multicolumn{3}{|c|}{$-40^{\circ} \mathrm{F}$} \\
\hline & 最高 & 最低 & 平均 & 最高 & 最低 & 平均 \\
\hline J.P-1 & 1.25 & 0.90 & 1.00 & 8.5 & 3.50 & 4.00 \\
\hline J.P-2 & - & 0.95 & - & 10.0 & - & - \\
\hline J.9-3 & 1.00 & 0.65 & 0.80 & 4.5 & 1.75 & 2.50 \\
\hline $\mathrm{N}-\mathrm{F}-4$ & - & - & 0.52 & - & - & 1.25 \\
\hline
\end{tabular}

\section{第14図 乾点の差異と析出点との関係}

（引火点 $100^{\circ} \mathrm{F}$ とした場合）

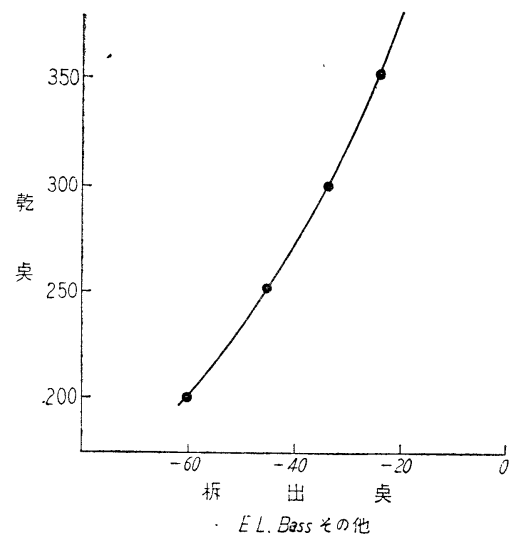

第15図 水の溶解性

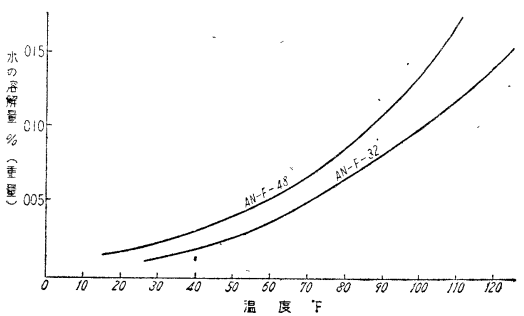

5. 始動性とカーボン附着性その他の関係

ジェット・エンデンの地上始動は外部よりの動力に よる圧縮機で多量の空気を供給して行うために，始動 性の良好なることは必要條件の一つである。始動性と 蒸発性の関係は第16罒のと抢りで，だいたい10\%溜出 溫度と直線的関係をもつている。

\section{第16図 始動性亡蒸発性}

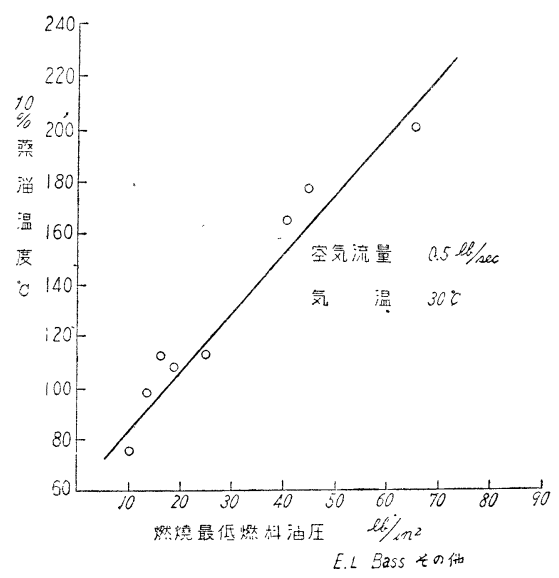

第17図 比重とカーボン附着量の関係

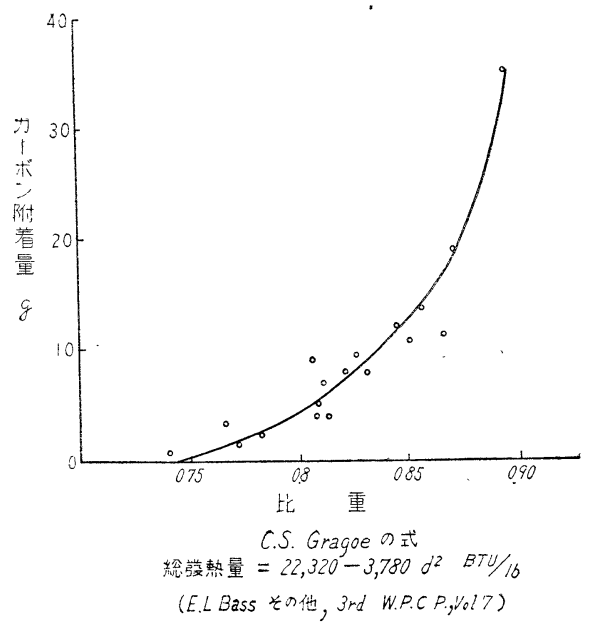


発熱量は燃料として必要條件であることは言をまた ないところであるが，タービンの犲根にカーボンの附 着することはェンデンの效率是下げるばかりでなく故 障の原因となる。燃料の比重が渭大するとその量は澶 大する。この関係は第17図のとおりである。な㧧黄 分のある種のものがこの傾向を触媒的に大にするとの ことであるが，詳細は略する。

前記各項目で燃料の性質と性能について記述したと ころであるが，燃燒性に最も大きな関係を有するもの は粘度ではないかとの推測は, 次の第 5 表によつて行 らこともも元て誤りでもないものと思う。

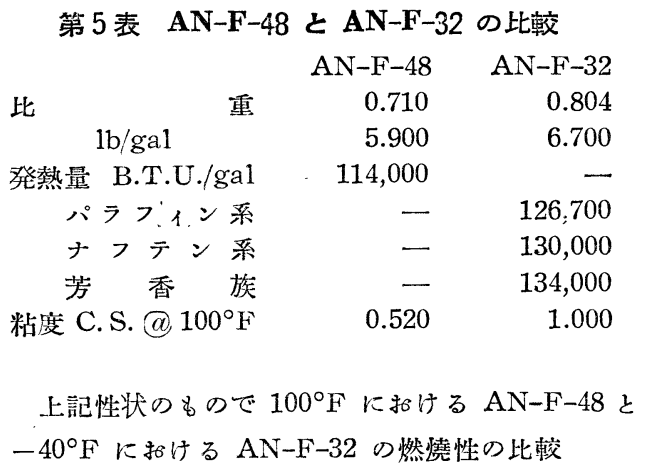

躓射角度做少 粒子大さ筜加 最低流量增加 流量範围娍少

$\begin{array}{cc}\text { 粘度燴加に } & \text { 密度燴加に } \\ \text { よ影響 } & \text { よる影 } \\ 8.0 \% & 0 \\ 16.0 \% & 0 \\ 40.0 \% & 12.0 \% \\ 18.0 \% & 0\end{array}$

以上の上うな事項が，卡の規格を考慮する場合に必 耍な基本的なものと考元られる。

\section{(IV) 結}

以上簡単に交献から航空ジェット・ェンヂンについ て調查紹介を行つたものであるが，燃料についてはそ の量㦃が第一問題であつて, しかも量詴による実用上 の少性を除去することが今後に残された問題であると 思ら。ここにはふれれなからが, 航空エンヂンと共 に，むるいはより以上急速に, 舶用ガスタービン・エ ンヂンがわが国においても実用化をはかられる可能性 が大きい。この場合には経済上より劣質燃料の使用さ れることは当然のことである。その場合必然的に噴射 の困蜼性，カーボンの蓄積，火焔の伸び過ぎなど種々 の問題力起きて, 実用燃料の規格範囲決定上に種々な 基本的，実用的研究を要することとなるのは明らかな ことである。このように考えてみると，ジェット燃料 について，まことに今後の研究にまつべき問題は多々 あるものと言うべきである。

\title{
Jet Engines and Fuels
}

\author{
By Takezo Obata
}

(Mitsubishi Oil Co.)

\begin{abstract}
SYNOPSIS :-The superior characteristics of jet engines are pointed out with a brief description of the performances and kinds of the present jets. The fuel for jet engines is characterized, according to the fuel standards of Britain and U.S. A., by its combustion properties, volatility variation in the high air, fluidity, filtering property, starting property, carbon deposition etc. The lack of the investigation on jet fuel in this country is forewarned by the author.
\end{abstract}

